\title{
TISSUE RESPONSE TO AIRBRASIVE POWDER, TO PULVERIZED ENAMEL AND DENTIN
}

\author{
DONALD A. KERR, D.D.S., M.S., SIGURD RAMFJORD, L.D.S., Рн.D., \\ AND GRETA GRAPE-RAMFJORD, L.D.S., M.S. \\ University of Michigan School of Dentistry, Department of Oral Pathology and \\ Periodontia, Ann Arbor, Mich.
}

\section{INTRODUCTION}

W

HEN the airbrasive technic for cavity preparation is used, there is always a hazard that some of the powder, tooth substance, and old filling material will be inhaled or introduced into the adjacent gingival tissues. It seemed desirable, therefore, to investigate tissue reactions to these substances.

According to specifications from the manufacturer of the airbrasive powder, ${ }^{*}$ it contains $\mathrm{Al}_{2} \mathrm{O}_{3}-94.56$ per cent, $\mathrm{SiO}_{2}-2.23$ per cent, $\mathrm{TiO}_{2}-2.75$ per cent, $\mathrm{FeO}-0.41$ per cent, $\mathrm{CaO}$-trace. The particle size is specified by the company to be between 10 to 50 microns (average, 40 microns). A cursory study of the powder smeared on a glass slide and placed under a microseope revealed that there were numerous particles present with particle size less than 10 microns, but no conclusive study was undertaken on particle size. One component of the formula, silica, is known to produce definite toxic effects resulting in a granulomatous reaction. The effect of aluminum oxide is controversial. It is claimed to be inert ${ }^{1}$ by some investigators and toxic by others. ${ }^{2-4}$

That implanted teeth are gradually resorbed is well established, but no report could be found on the fate of finely pulverized enamel and dentin implanted into living tissues. In reaction to dust, particle size is a very important factor with increasing tendency for granulomatous reaction with smaller particle size. ${ }^{1}$

\section{METHOD}

It has been established by MeCord and others ${ }^{5,6}$ that Miller and Sayers ${ }^{\text {7 }}$ method of intraperitoneal injection of sterile dust in saline suspension is the most satisfactory way to test general tissue reaction to a particulate foreign material. These authors ${ }^{8,9}$ considered 60 to 90 days to be a sufficient time interval for evaluation of tissue reaction to a given dust.

For this study, 59 adult guinea pigs were divided into 4 groups and intraperitoneal injections of the various test materials were administered. Each pig in Group I (18 guinea pigs) received 0.2 gram of new airbrasive powder in saline suspension. In Group II (14 guinea pigs) each received 0.2 gram of used airbrasive powder. In Group III (13 guinea pigs) each received, in saline

This report is from part of an investigation which was carried out under contract GA-49-007-MD-138 with the Medical Research and Development Board, office of the Surgeon

Received for publication Aug. 25, 1956. 5, $\mathbf{P a}$.

*S. S. White Dental Manufacturing Company, 211 South Twelfth Street, Philadelphia 
suspension, 0.2 gram of pure powdered enamel that had been passed through a 350 -mesh sieve (allowing passage of particle sizes up to 35 to 38 microns). Each pig in Group IV (14 guinea pigs) received 0.2 gram of dentin powder which also had been passed through a 350 -mesh sieve.

The animals were killed after 90 days and necropsy performed. Specimens from the lower abdominal wall, the omentum, the liver, and the spleen were removed for microscopic study.

Using an ordinary airbrasive unit, a stream of new airbrasive powder was directed at the gingival tissues of 5 adult rabbits at 2 places on each animal. The rabbits were killed after 50 to 365 days, and sections for microscopic study were prepared from 2 of the animals. The specimens included the jaws, teeth, and gingiva at the sites of the deposited airbrasive powder.

The sections were stained routinely with hematoxylin and eosin, and some of the sections from each group were stained with Azan connective tissue stains.

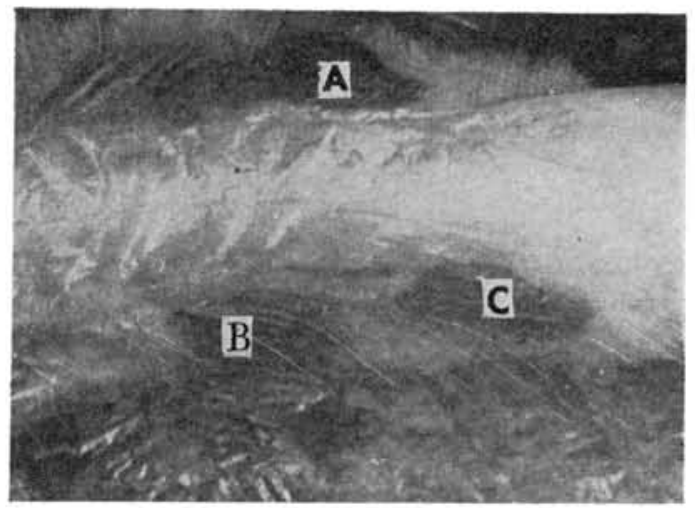

Fig. 1.-Plaques $(A, B, C)$ of airbrasive powder adherent to the low abdominal wall on both sides of the midline.

\section{Gross Pathology.-}

FINDINGS

The new and used airbrasive powder was localized in grayish, flat, irregular masses, mostly on the peritoneal surface along the lower midline of the abdominal cavity (Fig. 1). Some of these gray spots were also found in the mesenteric fat. The pigmented masses were dense to palpation and firmly adherent to the underlying and surrounding tissues. No inflammatory halo could be seen around them. The site of the injection was not visible grossly.

In the animals that had received injections of dentin and enamel powder, a light yellowish-brown pigment could be observed in the same locations as described for the airbrasive material. These areas appeared as diffuse serosal thickenings of the lower abdominal peritoneal surface, slightly firmer than the surrounding tissues, irregular and patchy in distribution. A few slightly pigmented spots were also observed on the omental surface. 


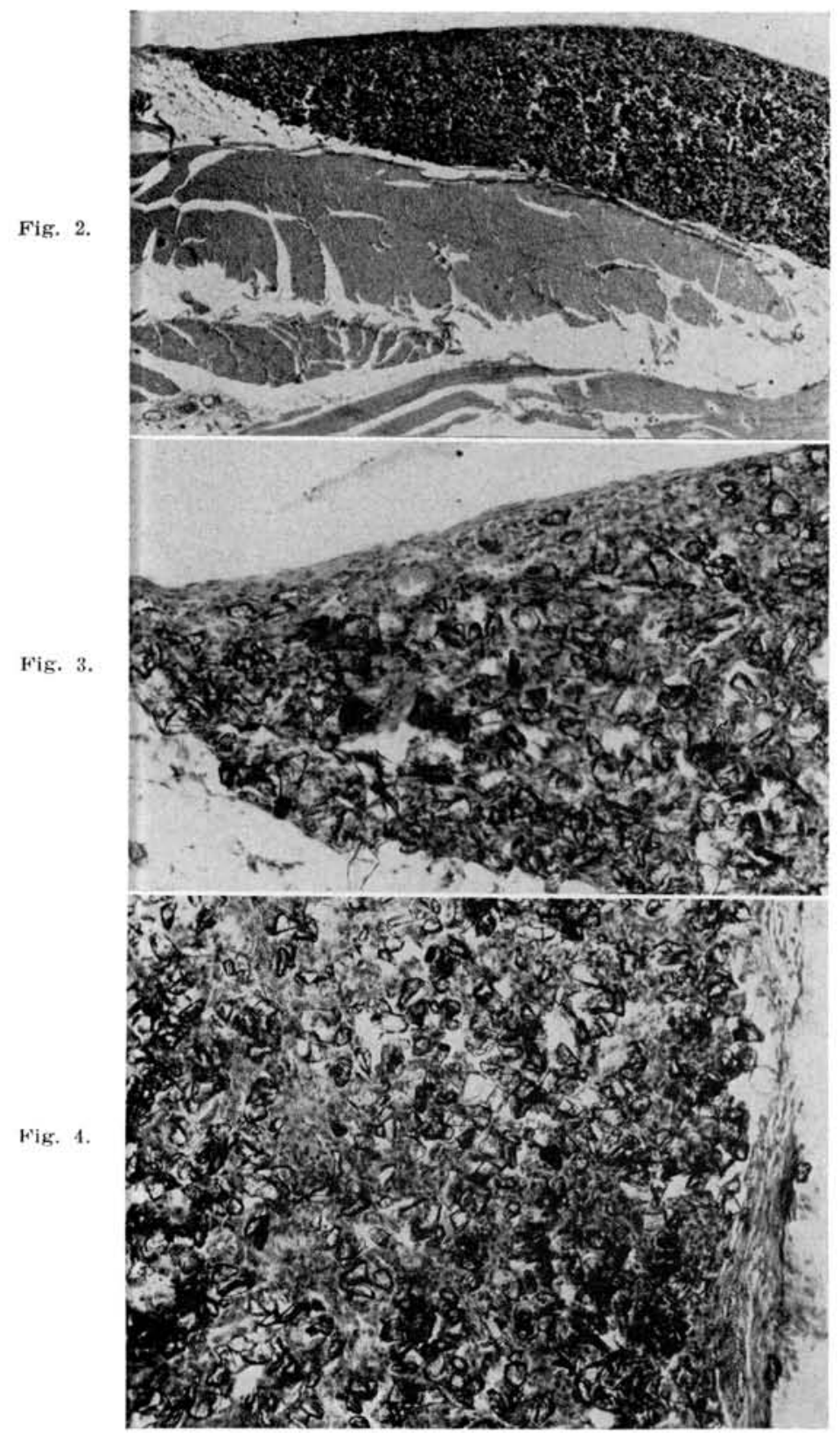

Fig. 2.-Section through a peritoneal plaque of airbrasive powder. (Orig. mag. $\times 15$.)

Fig. 3.-Fibrosis on peritoneal surface in reaction to airbrasive powder. (Orig. mag. $\times 252$.)

Fig. 4.-Mature connective tissue surrounding airbrasive particles. (Orig. mag. $\times 217$.) 


\section{Microscopic Findings.-}

A. New and used airbrasive powder: It was hardly possible to prepare artifact-free thin sections of the specimens containing airbrasive powder due to movement of the large particles during eutting, but adequate sections for detail studies were obtained.

The findings for the new and used airbrasive powder were essentially similar except that a few opaque particles without erystalline structure, thought to be amalgam, were present in the used powder only; but these particles did not in any way alter the tissue reaction. Therefore, the microscopic findings for the 2 groups will be discussed together.

Focal areas of chronic productive peritonitis and omentitis were observed around the masses of dust (Fig. 2). In the clumps and sheets of airbrasive

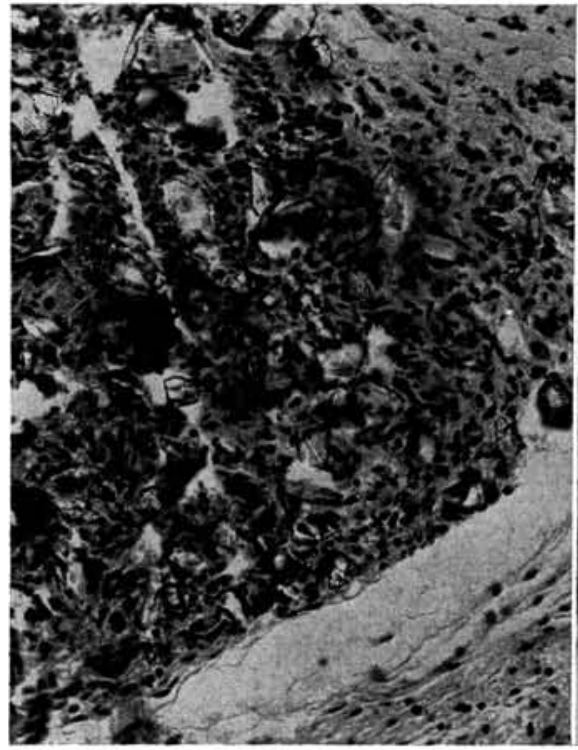

$A$.

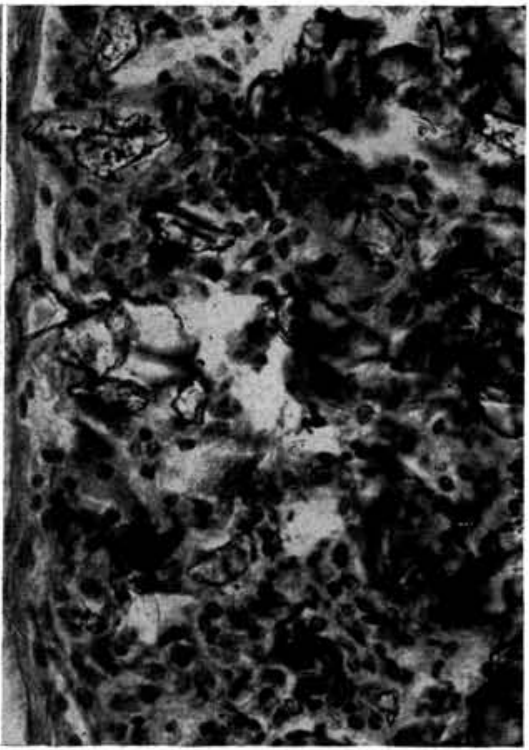

$B$.

Fig. 5.-A, Lymphocytes and plasma cells both in the immediate vicinity of the airbrasive particles and in the surrounding tissues. (Orig. mag. $\times 406$.)

$B$, High magniflcation (Orig. mag. $\times 686$ ) from Fig. $5, A$. Some particles have a shiny surface; others have dull, granular or black surface. Some particles are smaller than the nuclei of the adjacent cells. Chronic productive inflammation.

powder the individual particles were separated by a large number of proliferating fibroblasts (Fig. 3). Beginning collagen formation was present both at the periphery of the dust aggregations and between some of the dust particles in areas of mature connective tissue (Fig. 4). No necrosis of the type found in typical silicotic granulomas was observed and only a few giant cells were present. Some lymphocytes and a few plasma cells were observed in the immediate vicinity of the particles and occasionally spread rather far into the surrounding tissues (Fig. 5, A). The large dust particles had a shiny erystalline appearance, but some of the small particles appeared brown-black (Fig. 5, B). A large number of the particles were only 1 to 3 microns in their greatest diameters. It 
was difficult to ascertain whether these small particles were phagocytized or situated within the intercellular substances. A large number of cells had the appearance of macrophages. In some areas these cells were closely grouped together, and the boundaries between the nuclei were indistinct or not visible,

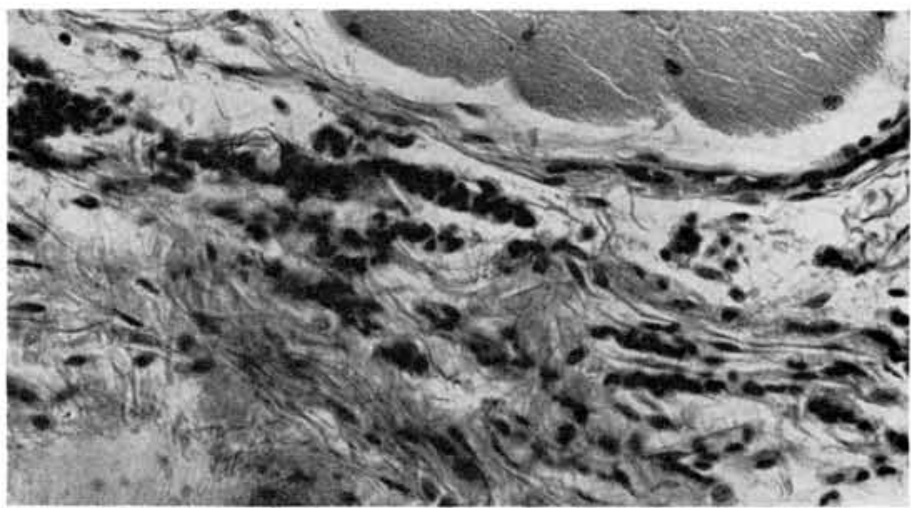

Fig. 6.-Mild myositis in abdominal wall adjacent to deposits of airbrasive powder. (Orig. mag. $\times 686$.)

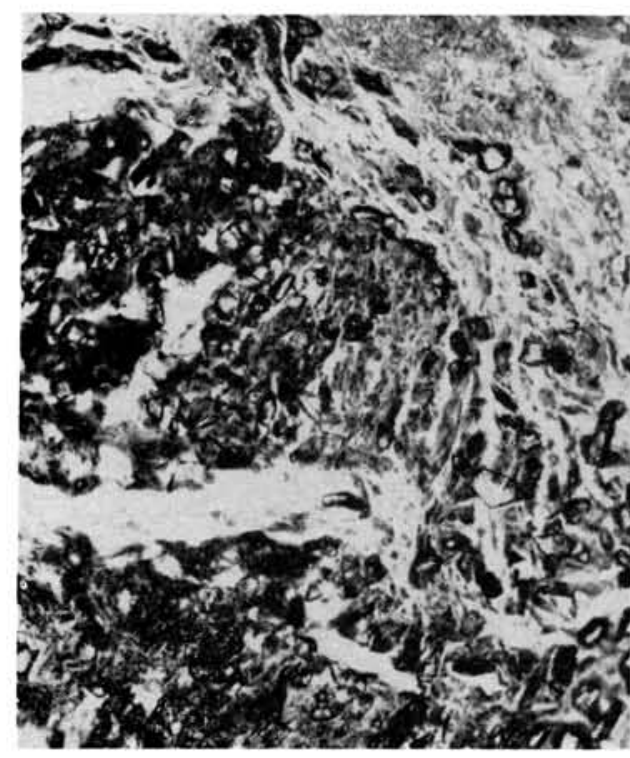

A.

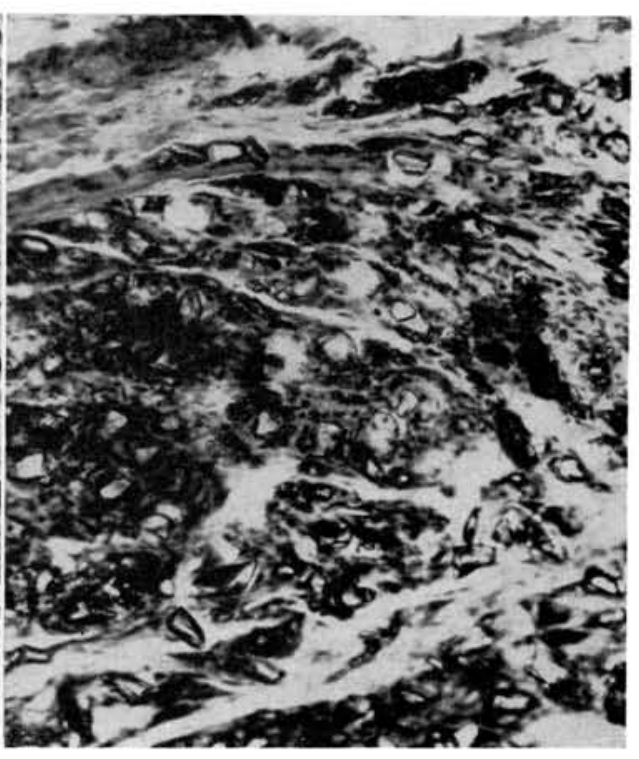

B.

Fig. 7.-A, Gingival fibrosis associated with deposits of airbrasive powder. From rabbit. Time of in observation 6 months. (Orig. mag. $\times 329$.)

$B$, Dense, mature connective tissue around airbrasive particles. No foreign body giant cell reaction. From free gingiva of rabbit. Time of observation 1 year. (Orig. mag. $\times 259$.)

giving these clusters of cells the appearance of aggregation giant cells. The amount of cytoplasm varied considerably. Some fine brown-black granular material was definitely phagocytized. This appeared as a very fine pigment within a large number of cells. A similar granular pigment appeared on the surface 


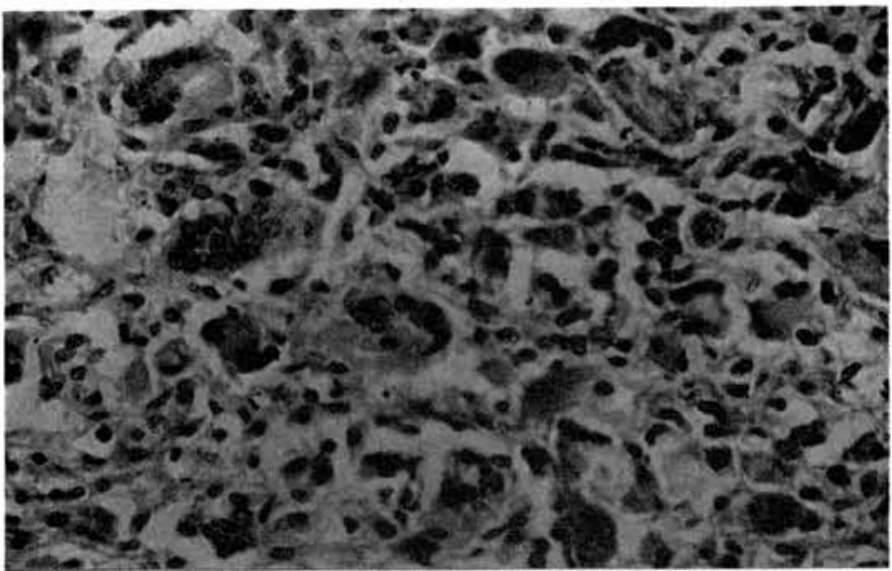

Fig. 8

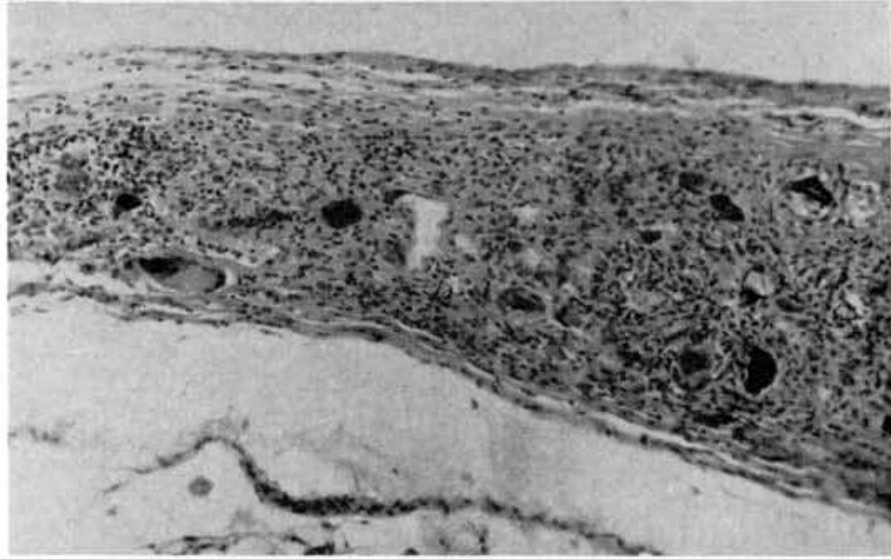

Fig. 9.

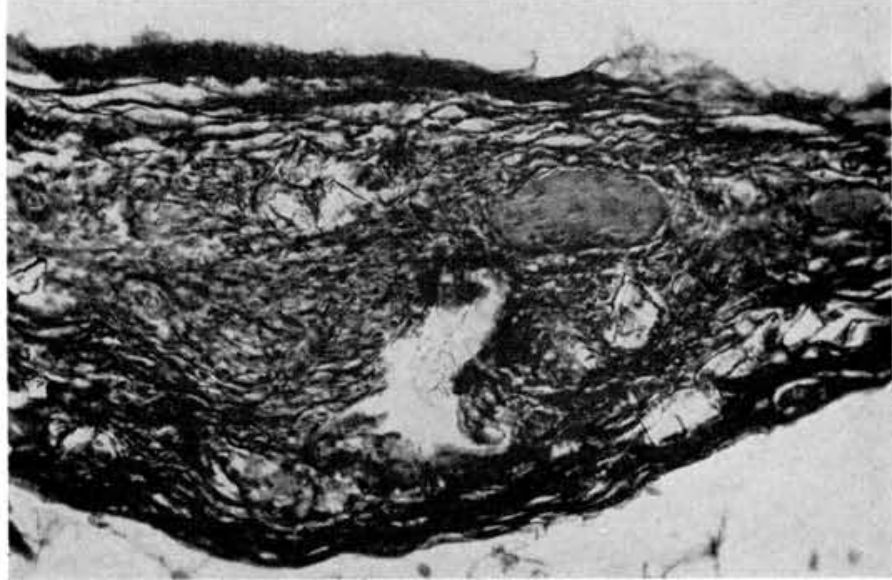

Fig. 10 .

Fig, 8.-Marked foreign body giant cell reaction to enamel dust. Phagocytosis of small particles. Chronic inflammation. Twenty-two day specimen. (Orig. mag. $\times 686$.)

Fig. 9.-Residual dentin dust and mild foreign body giant cell reaction. Fibrosis anc chronic productive inflammation. (Orig. mag. $\times 252$.)

Fig. 10.-Collagen formation in an area of peritoneal reaction to dentin dust. Azan stains. (Orig. mag. $\times 434$. 
of some of the dust particles which then had a dull surface in contrast to the shiny surface of the majority of the large erystals (Fig. $5, B$ ). No attempt was made to differentiate between the various types of dust particles $\left(\mathrm{Al}_{2} \mathrm{O}_{3}, \mathrm{SiO}_{2}\right.$,

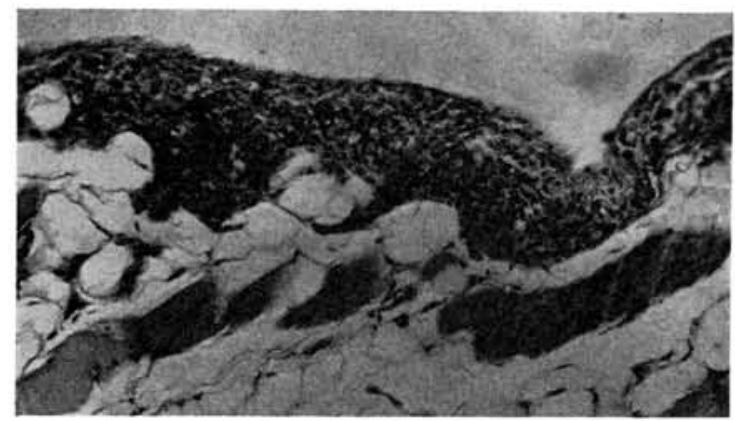

A.

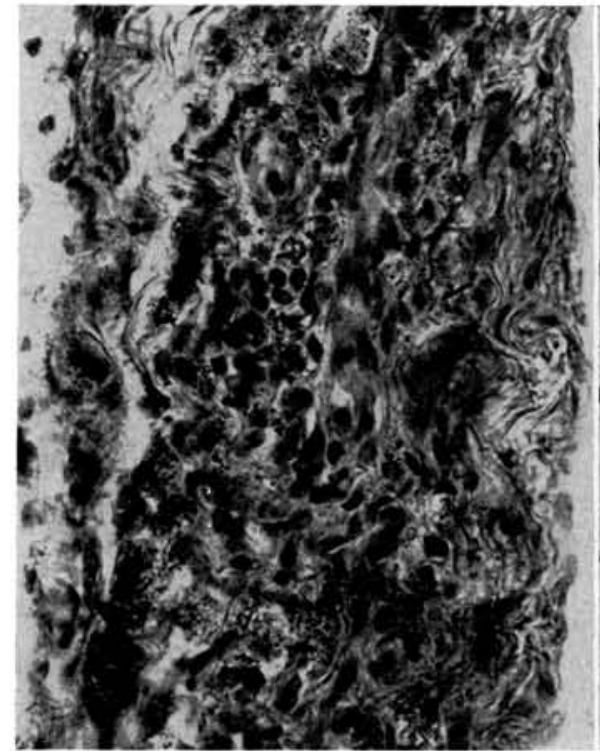

$B$.

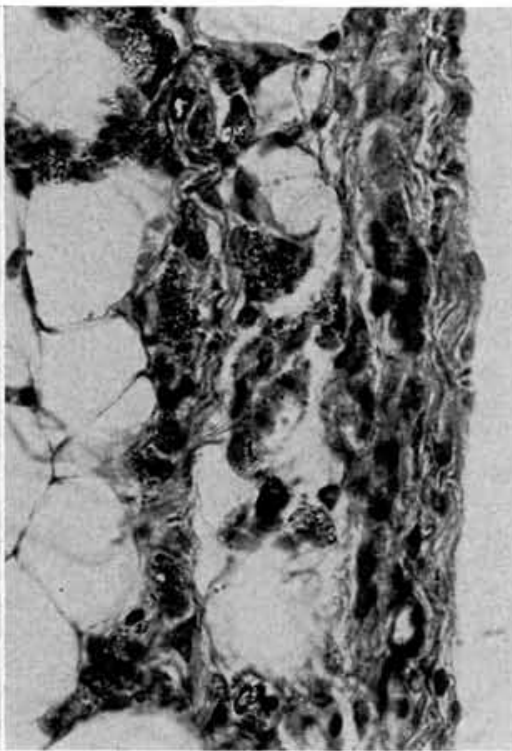

C.

Fig. 11- $-A$, Chronic productive inflammation and a narrow zone of flbrosis on the abdominal serosal surface. Reaction to dentin dust. (Orig. mag. $\times 217$.)

$B$, Chronic productive omentitis. Fibrosis. Phagocytized granular matter. Reaction to enamel dust. (Orig. mag. $\times 993$.)

$C$, Small particles phagocytized in large mononuclear cells. Reaction to enamel dust. (Orig. mag. $\times 993$.)

$\mathrm{FeO}$, and $\mathrm{CaO}$ ) within the tissues. No dust-containing lymph nodes could be found. A slight interstitial myositis was related to some of the masses of airbrasive powder (Fig. 6). No dust or any other abnormalities were observed in sections from the spleen and liver. 
The gingival reaction in rabbits to new airbrasive dust was similar to the intraperitoneal findings in the guinea pigs (Fig. 7, $A$ and $B$ ). There was practically no foreign body giant cell reaction, but a rather marked fibrosis. The 1year specimens showed an increased amount of fibrosis and collagen formation with the production of mature connective tissue as compared to the 6-month specimens. The mucosal membranes were intact over the deposits of airbrasive powder, and practically no inflammatory response could be observed. There seemed to be relatively fewer small particles present in the gingival tissues than in the intraperitoneal specimens. That might have been due either to elimination of the small particles by the body or to deeper penetration of larger particles when the powder was introduced into the gingival tissues.

B. Enamel and dentin: The microscopic findings for the enamel and dentin dusts were similar, and they are therefore discussed together.

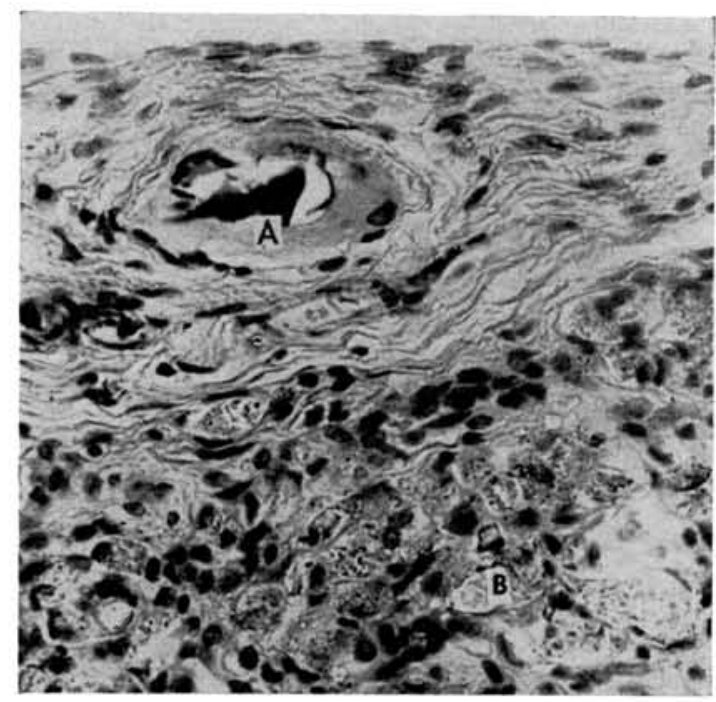

Fig. 12.- Small residual fragment of dentin (A) surrounded by flbrous connective tissue without foreign body giant cell reaction. Crystal $(B)$ also without foreign body giant cell reaction. Much phagocytized granular material. Chronic inflammation. (Orig. mag. $\times 993$.)

One animal that had received enamel powder was killed by the other animals in the cage after 22 days. A marked foreign body giant cell reaction was then present around the calcified particles (Fig. 8). Phagocytosis of small brown pigmentlike particles and active exudative and productive inflammation was evident in the areas of dust aggregations.

The rest of the specimens were from animals that had 90 days' exposure to the dust. Only occasional areas of a few calcified particles were found with little or no foreign body giant cell reaction around them (Fig. 9). There was a diffuse, mild, chronic productive omentitis on the peritoneal side of the abdominal wall, spread over much larger areas than the reaction to the airbrasive powder. A definite fibrosis could be observed on the serosal surface, evident 
also in the connective tissue stains (Fig. 10) as a residual effect of the dust. The fibroblastic activity in the areas of reaction to the dentin and enamel dust was of much milder degree than the reaction to airbrasive dust (Fig. 11, $A$ ). A large number of large foamy cells contained numerous brownish-black particles of granular pigment (Fig. 11, $B$ and $C$ ). This probably accounted for the light brownish pigmentation seen grossly. A few crystals, 10 to 30 microns in size, were embedded in the serosal surface with very little reaction to them (Fig. 12). These crystals were probably contaminants derived from the ball mill when the dentin and enamel were pulverized. In some of the specimens, a mild chronic myositis was observed in the abdominal musculature related to the areas of surface reaction. Specimens from lymph nodes, spleen, and liver were negative for dust and revealed no significant pathologic changes.

\section{DISCUSSION AND SIGNIFICANCE OF FINDINGS}

According to Miller and Sayers, ${ }^{8,} 10$ in addition to the usual foreign body reaction, there are 3 types of specific reaction to dust injected intraperitoneally : (1) The proliferative response is characterized by connective tissue nodules progressively inereasing in size, gradually becoming firm and fibrotic. (2) The inert reaction oceurs when the injected dust neither is absorbed nor initiates a proliferative response. The dust nodules will then become flattened and spread over a larger area. Fine particles are often phagocytized and spread in the surrounding tissues. (3) The absorptive response is characterized by irregular nodules which gradually disappear leaving a small area of fine particles at the site of the nodule. MeCord and his co-workers ${ }^{5,6}$ added 2 modified types of response: (A) A mixed response produced by dusts containing some free silica. The reaction is mainly inert, but a few silicotic nodules are found. (B) A miliary proliferative response which is a highly active response with small lesions scattered throughout the abdominal cavity.

It is difficult to classify the reaction to airbrasive powder into any of these specific reactions, but basically the response was slowly proliferative. Whether this proliferative response would ever reach a significant level, as in silicosis, is unknown. The indication is that it would not, since the reaction was so moderate after 90 days. The gingival response after a year was also rather insig. nificant and more of a scar tissue type than active fibroblastic proliferation. Similar observations were made by Naeslund on mixed silica and aluminum oxide dust. ${ }^{11}$ The large crystals seemed unaffected by body fluids. Whether the small aluminum-oxide crystals were attacked and gradually dissolved by the $\mathrm{NaCl}$ containing body fluids, as claimed by Jäger and Jäger, ${ }^{12}$ cannot be ascertained from this study; but it appeared as if some particles were disintegrating. Neither can it be stated if the proliferative response was due to the aluminum erystals or to the silica which allegedly was present in the powder. It was once believed $^{13}$ that the presence of aluminum safeguards against silicosis from the silica-containing dust due to the absorption of a layer of crystalline a-monohydrate of aluminum upon the particles of silica. About 1940-45 an extensive literature appeared on prophylactic and therapeutic use of aluminum dust for 
silicosis; but according to the more recent investigators, ${ }^{14}$ no definite beneficial effect has ever been proved to follow such practice. Furthermore, combinations of aluminum dust and silica have been found in autopsy cases with severe pulmonary damage. ${ }^{4}$ Therefore warnings against the use of aluminurn dust for this purpose have been given. ${ }^{14}$

It also has been claimed ${ }^{12}$ that the rate of ionization of aluminum and subsequent formation of toxic organic compounds of aluminum-protein salts is accelerated by the presence of mercury, but the old amalgam particles in the used airbrasive did not seem to affect the tissue reaction to the airbrasive powder. There are a few reports in the dental literature on proliferative inflammation around crystalline particles in the gingiva. ${ }^{15-19}$ In one case, ${ }^{19}$ the particles were proved to be silica, and in 3 other cases it was assumed that they probably were silica. Kollar, Wentz, and Orban ${ }^{20}$ abraded 12 healthy gingival papillae with airbrasive material and found very little inflammatory reaction to the crystals. Their claim that aluminum oxide crystals are inert cannot be accepted as proved since their time of observation, at the most, was 2 days. More significant is that in an area of pulpal exposure with the airbrasive technic, Patterson and Van Huysen ${ }^{21}$ did not find any inflammatory reaction to airbrasive particles after 60 days.

When a rotating brush and fine pumice are used for polishing teeth in the presence of gingival ulcerations, it is probable that some silica particles will be forced into the gingival tissues, superficially. Clinically, this does not seem to be of the same significance as, for instance, talcum powder left behind in the peritoneal eavity, probably because very little, if any, silica is incorporated within the gingival tissues following healing of these superficial wounds.

With the proliferative response (evident in this investigation) in mind, it appears that the introduction of airbrasive dust into the oral tissues constitutes an undesirable hazard producing a fibrotic response. Whether the proliferative reaction could be avoided by elimination of the silica from the airbrasive powder is not known.

The reaction to enamel and dentin would basically fall into reaction type III, the absorptive response, although some fibrosis also ensued from these dusts. The resultant mild fibrosis appears to make it undesirable to inhale considerable amounts of dentin and enamel dust as may occur when dentists "dry prepare" dental cavities and subsequently inhale the dust over many years. No inhalation experiments were undertaken for these dusts but, as previously stated, it is well established that the pulmonary changes are similar to the peritoneal changes. Therefore, it is probably advisable for the dentist to breathe through a filtrating mask if he routinely does his dental preparations in a dry field, although it should be emphasized that the reaction to these types of dusts is more of a "nuisance" than frankly irritative.

\section{SUMMARY}

1. New and used airbrasive powder initiated a mild proliferative response in the peritoneal cavity of guinea pigs and in gingival tissues of rabbits. It 
cannot, therefore, be characterized as being inert, and precautions should be taken against inhaling it or introducing it into oral tissues.

2. Powdered enamel and dentin primarily exeited an absorptive response in the intraperitoneal cavity of guinea pigs; but a slight fibrosis also resulted from these dusts. It appears undesirable to inhale them in extensive amounts over many years.

Acknowledgment is made to Miss Kate Mallory for preparing the histologic sections and to Miss Winnifred Arnold for photomicrography.

\section{REFERENCES}

1. Gardner, L. U., and Cummings, D. E.: The Reaction to Fine and Medium-Sized Quartz and Aluminum-Oxide Particles. Silicotic Cirrhosis of the Liver, Am. J. Path. 9: $751-63,1933$.

2. Goralewski, G.: Klinisehe und Tierexperimentelle Studien zum Frage der Aluminumstaublunge, Arch. f. Gewerbepath u. Gewerbehyg. 9: 676-89, 1939.

3. Marchi, A.: Über Experimentelle Aluminumstaublunge, Schweiz. Ztschr. Tuberk. 4: 413-33, 1947.

4. Shaver, C. G., and Riddell, A. R.: Lung Changes With the Manufacture of Alumina Abrasives, J. Indust. Hyg. \& Toxicol. 29: 145-57, 1947.

5. MeCord, C. P., Fleming, R. L., Ainslee, H., and Johnston, J.: The Measurement of the Harmfulness of Dusts for Humans Through the Agency of Animal Reactions, Surg., Gynec. \& Obst. 63: 129-37, 1936.

6. McCord, C. P., Kasper, J. A., and Brosius, W. L.: The Biologic Test for the Determination of the Fibrogenic Properties of Dust, Ohio State M. J. 33: 394-96, 1937.

7. Miller, J. W., and Sayers, R. R.: The Physiological Response of Peritoneal Tissue to Dust Introduced as Foreign Bodies, U. S. Pub. Health Rep. 49: 80, 1934.

8. Idem: The Physiological Response of Peritoneal Tissue to Certain Industrial and Pure Mineral Dusts, U. S. Pub. Health Rep. 51: 167-90, 1936.

9. Idem: The Response of Peritoneal Tissue to Industrial Dusts, J. S. Pub. Health Rep. 56: 264-72, 1941 .

10. Idem: Microseopic Appearance of Experimentally Produced Dust Nodules in the Peritoneum, U. S. Pub. Health Rep. 50: 1619, 1935.

11. Naeslund, C.: The Prevention of Silicosis: Experimental Investigations on the Action of Certain Non-silicous Dusts and Silica in the Origin and Development of Silicosis, J. Indust. Hgy. \& Toxicol. 20: 1-30, 1940.

12. Jäger, R., and Jäger, F.: Kolloid-Chemisches und Histo-Chemisches zur Frage der Lungenschädigungen durch Aluminumstaub, Arch. f. Gewerbepath. u. Gewerbehyg. 11: $117-30,1941$.

13. Denny, J. J., Robson, W. D., and Irwin, D. A.: The Prevention of Silicosis by Metallie Aluminum, Canad. M. A. J. 40: 213-27, 1939.

14. Brown, E. W., and von Winkle, W.: Present Status of Aluminum in the Therapy and Prophylaxis of Silicosis, J. A. M. A. 140: 1024-29, 1949.

15. Kaletsky, T.: Chronic Granulomatous Inflammation, Arch. Clin. Oral Path. 2: 70-73, 1938.

16. Spalding, G. R., and Orban, B.: Unusual Inflammatory Reaction of the Oral Mucosa, J. Periodont. 16: 127-35, 1945.

17. Orban, B.: Gingival Inclusions, J. Periodont. 16: 16-21, 1945.

18. Kramer, I. R. H.: Siliceous Granulomatosis of the Gingiva, Brit. D. J. 91: 309-13, 1951.

19. Marsland, E. A., and Fox, E. C.: A Case of Uleeration and Pain of the Gingival and Oral Mueosa Associated With the Presence of Silica, Brit. D. J. 99: 115-18, 1955.

20. Kollar, J. A., Wentz, F. M., and Orban, B.: The Reaction of Clinieally Normal Gingiva to Abrasive Injury, J. Periodont. 26: 95-98, 1955.

21. Patterson, S. S., and Van Huysen, G.: The Treatment of Pulp Exposure, Oral Surg., Oral. Med. \& Oral Path. 7: 194-206, 1954. 